\title{
HIGHER EDUCATION LEARNERS' ATTITUDES TOWARDS EMERGENCY ONLINE INSTRUCTION DURING COVID-19 PANDEMIC: THE CONTEXT OF TURKEY
}

\author{
Mohammadreza Valizadeh \\ Cappadocia University, Turkey \\ mrvalizadeh2015@gmail.com \\ Fatemeh Soltanpour \\ Kar Higher Education Institute, Qazvin, Iran \\ fatemeh.soltanpour@gmail.com
}

\begin{abstract}
This mixed-methods study aimed at investigating the Turkish higher education learners' attitudes towards Emergency Online Teaching (EOT) under the Covid-19 pandemic in order to discover the benefits and drawbacks of it. The participants were 251 higher education learners who received the EOT during the Covid-19 crisis in Turkey. Both qualitative and quantitative data were gathered by means of a questionnaire in August 2020. Quantitative data were obtained via closed-ended questions with the response on a Likert-scale format. Qualitative data were acquired through open-ended questions. The results showed that the hurried shift to an online instruction by universities in Turkey was not fully satisfactory and the majority of the respondents (74.1\%) preferred face-toface learning to the online format, however, the participants also stated that they felt safer during this pandemic disease thanks to the availability of distant online education. The drawbacks they mentioned included inadequate technological infrastructure or facilities, lack of sufficient teacher-student and peer interaction, lack of learners' attention and concentration, tediousness of online lessons, learners' inadequate engagement in class activities, as well as the absence of comprehensive assessment procedure.
\end{abstract}

Keywords: Emergency online teaching (EOT); Covid-19 pandemic; higher education learners' attitudes; context of Turkey.

\section{Introduction}

Online instruction has been defined as the delivery of teaching programmes utilizing the Internet (Chadha and Kumail, 2002), via which the learners can participate in an educational opportunity without being physically at the same location as their teacher (Kamal and Radhakrishnan, 2019, p. 408). The effective use of technology in the teaching and learning process has been of great concern to many educational systems (Njiku, Maniraho, and Mutarutinya, 2019) and several universities worldwide have accepted online or electronic learning (e-learning) to encourage and improve learning (Kamal and Radhakrishnan, 2019; Salloum et al., 2019).

The careful design of the online programme, responsive curriculum, choices of qualified and wellprepared instructors, availability of sufficient technology devices, and supportive stakeholders are all vital for the successful delivery of the lessons in an online mode (Barr and Miller, 2013). Besides the availability of appropriate infrastructures, such as internet quality and speed and ease of access to online resources, the readiness of both teachers and learners to adapt to this technology is also essential for the success of the distance online learning process (Cantrell et al., 2008; Kohan et al., 2017). Several of the mentioned factors can certainly be absent in emergency online teaching (EOT) during a pandemic which has caught the world in shock and has had adverse effects on various sectors worldwide. Higher education worldwide is among the sectors which have been affected due to the Covid-19 pandemic because millions of educational institutions experienced lockdown in a very limited span of time to enforce social distancing measures and educational institutions worldwide have been presented with daunting challenges in their systems of planning, implementation, and assessment (Toquero, 2020). Consequently, EOT is a temporary shift of instructional model to an alternate format due to crisis circumstances. In contrast to well-planned and carefully designed online instruction, EOT involves the use of fully remote online teaching in lieu of instruction that would otherwise be provided face-to-face or as blended courses and that will certainly return to that format once the crisis or emergency has been alleviated. The rapid approach needed for EOT may reduce the quality of the courses run (Hodges et al., 2020).

Some universities in Turkey have adopted well-planned online learning for more than a decade either for their all departments and faculties or for only one department or a few ones as needed (Kaya, 2012). Some previously done studies on online learning in Turkey found promising results in terms of students' performance and attitudes (Cakir and Solak, 2015; Cinkara and Bagceci, 2013; Eren, 2012; Inal and Korkmaz, 2019; Simsek, 2008; Uzun and Senturk, 2010) although in a recent study by Erarslan and

(C) Mohammadreza Valizadeh, Fatemeh Soltanpour. 2021. Published by Igor Sikorsky Kyiv Polytechnic Institute. This is an Open Access article distributed under the terms of the licence CC BY 4.0 
Topkaya (2017), it was found that online course did not help learners in terms of their overall success at English preparatory instruction, yet the learners had "partly positive attitudes towards online course" (p. 80). Moreover, Tekinarslan's (2008) analyses of demographical characteristic differences revealed that "married learners, working learners and learners with children have significantly higher attitude levels toward" InternetBased Learning (IBL) in comparison to the learners who were "unemployed and single and learners with no children." Male learners proved to have "significantly higher attitude levels than females." Besides, "learners over age of 26 had statistically higher attitude levels than those of younger learners. Attitude levels of learners with poor GPAs were significantly lower than those of learners with better GPAs." (Tekinarslan, 2008, p. 67).

The above-mentioned studies in Turkey explored the efficacy and the attitudes of learners towards blended learning, in which students receive both online and face-to-face instruction. In addition, the stated studies were done in ideal conditions in which the electronic infrastructure was provided and the participating learners were ready and willing to participate in the study. However, it is acknowledged that due to the requirement of social distancing during the Coronavirus pandemic, many educational institutions worldwide adopted EOT, as the alternative to the fac-to-face instruction (Hodges et al. 2020; "Policy brief: Education during COVID-19 and beyond," 2020) in response to university closures in the time of crisis.

Similarly, in Turkey, there was a sudden shift from the traditional face-to-face education model to the online one. Even though a few Turkish universities were already utilizing distance online education, it was not widespread in Turkish higher education. The pandemic compelled Turkish universities to enhance their technical infrastructure and teach learners online so as not to interrupt their academic studies (Erkut, 2020; Gunes, 2020). Well-planned online education systems are meaningfully different from courses run online due to a crisis (Hodges et al., 2020) and unfortunately, as Turkish experts acknowledged, the Turkish higher education system was neither well-prepared for the pandemic crisis of this proportion, nor ready for effective online instruction (Erkut, 2020). Therefore, a question arises whether or not the EOT in higher education in Turkey under the Covid-19 pandemic has been perceived as useful by the learners.

Given the fact that quality service can "positively affect the behavioural intent of students and teachers to implement e-learning technology" (Salloum et al., 2019, p. 514), and the learners' perceived ease of use, attitude, and satisfaction of online learning have a positive effect on their academic achievement (Cakir and Solak, 2015; Chen and Tseng, 2012; Ilgaz and Gülbahar, 2015), investigating what the learners of online learning think about it is very important because their attitudes towards online learning is one of the vital issues related to taking the advantage of and being successful in learning (Tallent-Runnels et al., 2006; Hodges et al., 2020). Students' feedback is also important for further improvement of the learning process (Syauqi et al., 2020). As a result, this study has addressed the following questions:

1. What are the attitudes of the higher education learners towards online instruction during the Covid-19 pandemic in Turkey?

2. What are the benefits and drawbacks of online education during the Covid-19 pandemic in Turkey?

\section{Methods}

This study has a mixed-methods design, including both quantitative and qualitative approaches. In terms of the sampling strategy, purposeful sampling was utilized in order to select cases from which plenty of insights and in-depth understanding about issues of considerable importance for the purpose of the inquiry can be yielded (Patton, 2014).

\section{Participants}

The participants were 251 Turkish higher education learners who received the EOT under the Covid-19 pandemic. The students who responded to the research survey were studying undergraduate programmes in Foreign languages, Management, Law, and Engineering at Gazi University, Dokuz Eylul University, Akdeniz University, Bilkent University, Istanbul University, and Ankara University, all of which are in Turkey. Table 1 provides a summary of participants' background characteristics.

Table 1. Participants' background characteristics

\begin{tabular}{|c|c|c|c|}
\hline & & Frequency & Percentage \\
\hline \multirow[t]{2}{*}{ Gender } & Female & 165 & 65.7 \\
\hline & Male & 86 & 34.3 \\
\hline \multirow[t]{3}{*}{ Educational Level } & Preparatory University & 94 & 37.5 \\
\hline & Undergraduate & 115 & 45.8 \\
\hline & Post-graduate & 42 & 16.7 \\
\hline \multirow[t]{2}{*}{ Age } & Mean & & \\
\hline & 6.393 & & \\
\hline
\end{tabular}




\section{Instruments}

Data were gathered by means of a questionnaire, which was designed to collect both qualitative and quantitative data. The questionnaire incorporated the adapted items which had already been developed by Shahzad et al. (2020). Both authors of the present study carefully thought about the original items in the questionnaire to improve them in terms of wording and clarity. In addition, Shahzad et al.'s (2020) study focused on the English as a Second Language (ESL) learners' attitudes during Covid-19 circumstances while the current study focused on higher education learners in general. Therefore, the items in the original questionnaire which focused specifically on ESL issues were removed. Moreover, in order to pursue the whole aims of the research, open-ended questions were added to the original questionnaire. Therefore, quantitative data were obtained via close-ended questions with the response on a Likert-scale format. Qualitative data were acquired through open-ended questions.

The questionnaire included three sections. The 1st section provided biodata about the participants' gender, age, and educational level. The 2nd section incorporated two kinds of questions. Thirty items on a Likert scale inquired about the participants' attitudes towards their received online learning. The participants needed to read the statements and select one of the options of 'Strongly Disagree', 'Disagree', 'Not Sure', 'Agree', and 'Strongly Agree'. Five questions were open-ended and required greater elaboration on why they agreed or disagreed with the statements.

\section{Data Collection Procedure}

Before the study was carried out, the questionnaire was piloted with a similar group of 20 learners, who were asked to respond to the questions, provide feedback on the wording, clarity, and, improvement of the items. No item was found as vague or confusing. The reliability of the questionnaire, estimated via Cronbach Alpha, was .852, indicating a preferred level of internal consistency (Pallant, 2013).

According to the principles of purposeful sampling, the sampling in this research was not biased. The research targets were all the university undergraduate students who had experienced the EOT during the Covid-19 pandemic in Turkish universities. Therefore, based on Creswell and Clark (2011), the researchers tried to identify and select the higher education students who had the experience of EOT during the Covid-19 pandemic in Turkish universities. Moreover, the factors of availability and willingness to participate, as well as the ability to communicate experiences and opinions in an articulate, expressive, and reflective manner were also essential to consider (Bernard, 2006). As a result, one of the researchers of the present study submitted the questionnaire to several university students he knew. He also asked his colleagues to submit the questionnaires to their university students, who had the required criteria (i.e., the experience of EOT during Covid-19 in Turkish universities). Each student was also asked to send the questionnaire to his/her peers who had the required criteria based on the research purpose. Totally, the questionnaire was distributed to 302 learners of online learning, studying at different universities in various cities of Turkey. Their participation was voluntary and distributed via online Google Form. Learners were informed that by completing and returning the questionnaire, they had consented to participate in the study. Learners responded to the questionnaire anonymously. Out of 302 learners, 251 students, who were willing to participate and express their opinions, completed and submitted the questionnaire.

Data Analysis

Data from the close-ended items in the questionnaire were analyzed in terms of frequencies and percentages of the responses, using SPSS 22. The written responses to the open-ended questions provided qualitative data which were analyzed using a method of thematic analysis (Guest, MacQueen, and Namey, 2012) by both authors separately. First, they read the participants' responses so that they learned about the data. Then, using MAXQDA 10 and utilizing both inductive and deductive approaches (Reichertz, 2014), several preliminary codes (themes) were identified and assigned to the survey data. Next, these preliminary themes were reviewed and refined by gathering relevant themes which referred to similar concepts. Finally, in order to reach a consensus agreement in which both authors as coders agree on all codes when the categorization was finished, both authors had a meeting, reviewed all the responses and codes, discussed the similarities and differences in their codes and resolved all differences. This process was done to achieve inter-rater reliability. Additionally, to obey the principle of credibility in qualitative research, which concerns the truthfulness of the findings, the researcher employed the strategy of member checking by sharing the data and interpretations with 20 participants in the research to see if they agree; via this strategy, the researchers ensured that their understanding of the research participants' perceptions was as accurate and complete as possible (Nassaji, 2020). 


\section{Results and Discussion}

\section{Turkish Higher Education Learners' Attitudes towards the EOT}

First off, it should be noted that the percentages in the text below were obtained with the sum of agree and strongly agree or disagree and strongly disagree. Two items in the questionnaire investigated the participants' preferences for either online or face-to-face learning. The answers to the item stating "Face-toface learning is better than online learning" demonstrate that a large number of the participants $(74.1 \%)$ preferred face-to-face learning to online learning, while very few respondents $(12.4 \%)$ had the opposite idea. The responses to the other item stating "Online learning is better than face-to-face learning" do not seem contradictory because again a few participants $(16.8 \%)$ showed agreement and two-thirds of the participants $(65.8 \%)$ stated that online learning is not better than face-to-face learning. $42.7 \%$ of the learners claimed that online teaching does not ensure quality learning while only a few $(25.5 \%)$ disagreed with them. $43.8 \%$ of the participants believed that online learning is problematic while only $28.3 \%$ did not believe so. About half of the learners $(43.5 \%)$ acknowledged that online learning can be helpful only in particular circumstances whereas fewer learners (21.9\%) disagreed with them. Over half of the learners (59.7\%) believed that students are compelled to learn online in specific circumstances and the majority of the respondents $(74.1 \%)$ preferred face-to-face learning to an online format. Similar preferences were also revealed in some of the studies of online instruction during the Covid-19 pandemic in Malaysia (Chung et al., 2020), Jordan (Alawamleh et al., 2020), and Albania (Xhelili et al., 2021).

As for their reasons, which can be attributed to the instruction or teachers, $42.6 \%$ of the learners claimed that teachers are not easily accessible in online learning while about a third of the participating students (32.3\%) did not think so. One-third of the learners $(33.1 \%)$ were not sure whether online learning fulfilled their learning needs and approximately the same number of the learners (31.8\%) claimed that online learning could not fulfil these needs. Other studies reported 'adjustment of learning styles', which is an important factor pertinent to the students' learning needs, as one of the barriers to online learning during this crisis (Baticulon et al., 2021; Khalil et al., 2020).

$29.5 \%$ of respondents found that online learning engages students, $41 \%$ of them were not sure about it. Over half of the participating learners (59\%) stated that not all students actively participated in online learning whereas only one-fifth $(22.7 \%)$ of them disagreed with it. Inadequate students' engagement in online class activities was also reported as a challenge of online instruction during this pandemic by other researchers from different countries (Sreehari, 2020; Xhelili et al., 2021).

Although nearly half of the learners $(48.2 \%)$ were satisfied with the audio-video quality, less than a third $(30.3 \%)$ were not satisfied with it. $41 \%$ of students believed that teachers were ready to teach online, yet about a third (32.6\%) of them did not think so and approximately a quarter (26.3\%) of participants were not sure about it, which means they were not fully satisfied with their teachers' preparedness for teaching online. Studies done in some other countries also revealed that most of the teachers were not well-equipped with online teaching methods and had to adapt to the change due to the Covid-19 crisis (Tan, 2021). For example, in Syauqi et al.'s (2020) study, the Indonesian students of Mechanical Engineering complained that their teachers' management of online learning did not accord with students' expectations and that online learning during the Covid-19 pandemic did not provide "better experience and productivity in mastering competencies" (p. 881).

Nearly half of the learners (48.3\%) in the present study stated that the instructions of the teachers were easily understandable for the students in online learning whereas $27.1 \%$ did not agree and $24.1 \%$ were not sure about it. Having difficulty in understanding online course materials during the pandemic was also reported by other researchers worldwide (Alawamleh et al., 2020; Allo, 2020; Chung et al., 2020; Khalil et al., 2020; Subedi et al., 2020). In a recent study done by (Chung et al. 2020) during the coronavirus pandemic in the context of Malaysia, the majority of the participants argued that understanding the content of the subjects was a big challenge, so they did not want to continue studying online.

Above a third of the learners (37.8\%) stated that they were not sure if relevant training was provided to them to facilitate their online learning. To elaborate on this point, it should be noted that all the respondents said that they had received training to facilitate their online learning, but over a third of them stated that their being trained was done just by using a pamphlet which they had to study to be able to utilize the online education platform, and the pamphlet was not fully comprehensive; for example, it did not include information on how to handle technical problems the students faced during online learning; that's why they wondered whether the received training was relevant enough.

In other contexts, similar results can be seen. For example, nearly half of the Albanian students in Xhelili et al.'s (2021) study had difficulties in learning the course materials because of the lack of familiarity with technology. Adnan and Anwar (2020) also pointed out that online learning cannot yield beneficial 
results in developing countries due to technical and financial problems. As an example, Dube (2020) found that although the South African government promoted online learning as the only option in the crisis of COVID-19, this mode excludes many rural learners from education because of a lack of resources to connect to the internet and low-tech software. Similarly, Muthuprasad et al. (2021) indicated that broadband connectivity issues in rural areas of India created a challenge for students in learning online programmes. Baticulon et al. (2021) showed that domestic issues related to home or family, particularly, financial distress are among the challenges to online learning in the Philippines.

$44.3 \%$ of the learners said that students faced emotional and behavioural problems in online learning; however, $28.3 \%$ were not sure about it. About half of the learners (47.4\%) said that students are afraid of or feel stressed over online learning, yet less than a third of the respondents $(30.3 \%)$ disagreed with them. Similar problems were experienced by students in other countries. In Indonesia, over a third of the undergraduate students of Dentistry in Amir et al.'s (2020) study experienced stress while distance learning during the Covid-19 pandemic. Many first-year students in the U.S felt anxiety in distance learning during the Coronavirus outbreak (Unger and Meiran, 2020). Malaysian students in Tan's (2021) research were also stressed with their online study during this crisis. Albanian students in Xhelili et al. (2021)'s study also stated that online exams caused more anxiety for them than examinations in the classroom.

Over half of the participants argued that the availability of the Internet is not ensured for all the students while a few $(25.1 \%)$ disagreed with them. Internet connection was also reported as a huge challenge in some other studies in other contexts (Amir et al., 2020; Baticulon et al., 2021; Chung et al., 2020; Dube, 2020; Hussein, et al. 2020; Khalil et al., 2020).

\section{Drawbacks and Benefits of the EOT}

The participants who acknowledged that (a) online learning is problematic, (b) not all students are ready and willing to get online teaching, and (c) face-to-face learning is better than online one were required to elaborate on their reasons through three open-ended questions. The learners who believed that online learning is better than face-to-face one were required to elaborate on their reasons through an open-ended question. Moreover, there were respondents who clearly acknowledged that online learning can be helpful only in particular circumstances; they were required to specify the circumstances by means of another openended question. The whole responses were clustered around one benefit and six drawbacks.

Table 2. Benefits and Drawbacks of online learning

\begin{tabular}{llc}
\hline \multirow{2}{*}{ Benefits } & $\begin{array}{l}\text { Feeling safe during a pandemic disease thanks to the } \\
\text { available distance education }\end{array}$ & Frequency \\
\hline Drawbacks & Inadequate technological infrastructure or facilities & 61 \\
\cline { 2 - 3 } & Lack of sufficient teacher-student and peer interaction & 56 \\
\cline { 2 - 3 } & Lack of learners' attention and concentration & 34 \\
\cline { 2 - 3 } & Tediousness of online lessons & 16 \\
\cline { 2 - 3 } & Learners' inadequate active engagement in-class activities & 14 \\
\cline { 2 - 3 } & Non-existence of comprehensive assessment procedure & 4 \\
\hline
\end{tabular}

As table 2 indicates, the Turkish higher education learners believed that the main advantage of virtual education in this crisis is that they feel safe during this pandemic disease, because via distance education, they do not have to be outdoors and endanger their health. Otherwise, several higher education students have to commute from where they reside to the city where the university is located, which in this pandemic, can be harmful to their health. The followings are some of the excerpts from their responses. The following are some of the excerpts from their responses.

Because of the coronavirus pandemic, I don't feel safe if I study face-to-face. Distance education is more convenient in the current conditions.

Pandemics like COVID-19 can make face-to-face learning problematic, so distance learning is a valuable option. By virtual learning, we are not at risk, so it is enjoyable and effective.

In this circumstance - Coronavirus pandemic - online learning is a must for us because there are many students that come from the countryside or other cities and travelling can be really dangerous for their health. 
During the Coronavirus pandemic, face-to-face learning threatens students' lives, especially those who commute to university from other cities or villages. Online learning reduces the hectic trouble of transportation, in this pandemic.

These benefits were also mentioned in some of the other studies. For example, Bączek et al. (2021) reported 'the ability to stay at home in comfortable surroundings' as the most frequent advantages of elearning stated by Polish medical students. Additionally, the factor of 'safety' was also reported by the university students, studying general English in United Arab Emirates (Hussein et al. 2020).

However, the first and most frequently mentioned problem by the Turkish higher education students in the current study, causing dissatisfaction, was 'inadequate technological infrastructure or facilities'. The students complained that they frequently experienced various technical problems, such as lack of internet access and connection, power failures, or computer problems, which all posed considerable difficulty. Samples of the participants' responses are as follows:

I prefer face-to-face training because there are problems such as Internet disconnection, so we can't join the classes and can't learn anything.

Sometimes there can be problems with the internet, power outages, or computer problems, which can create hard times for us.

Similarly, the students pointed to 'inadequate technological infrastructure or facilities' as the main reason for not being ready and not willing to receive online teaching. These are some excerpts from their responses.

If internet access and lecture listening tools are available to all students in the country, then all students can attend online classes, but many of us find it difficult to attend online classes in our homes; many of us do not have access to computers or decent internet connection which will always be a big issue. Also, the electricity can really be unpredictable at times. I've had many cases where my electricity went off in the middle of a class.

I don't think most students are ready and willing because there are people who do not have a computer and cannot afford it. There are people who have old electronic devices, such as old PC without working webcam or there are people who do not have access to the Internet, so they cannot use online classes.

Because of the situation of the coronavirus, many of us are in our villages, so such students can't connect to the online classes. Not every student has an Internet connection, personal computer, or smartphone. There are students who aren't able to use online resources due to not having access to technological equipment.

'Inadequate technological infrastructure or facilities' was also reported as problematic by other researchers in other contexts worldwide, such as in the United Arab Emirates (Hussein et al. 2020), Indonesia (Allo 2020; Amir et al. 2020), South Africa (Dube 2020), Argentina (Villanueva et al. 2020), Saudi Arabia (Khalil et al. 2020), South India (Sreehari 2020), Poland (Bączek et al. 2021) and the Philippines (Baticulon et al. 2021).

The second-ranked issue of causing dissatisfaction was 'lack of sufficient teacher-student and peer interaction'. These are some of the students' responses.

Virtual learning is problematic in many ways for most people, but the main reason is interaction issues. Lack of tools for proper interaction makes online learning challenging.

Students do not get enough feedback. One-sided lecturing is boring; I cannot ask my questions and get the answer easily. In online education, I feel as if I am watching a video from YouTube. Interaction and class participation are important.

Eye contact, real communication, direct interaction cannot be provided in a virtual environment. Faceto-face training is definitely more efficient.

During the face-to-face teaching, I would feel better if I have my friends around me to share my opinions and questions about the lesson. I find dialogues with my friends really helpful to better understand the topics covered during the lesson.

Since face-to-face instruction takes place in the classroom environment, you can easily interact with the instructor and classmates and talk about an idea. In online lessons, there is no effective in-class interaction due to late reading of the message sent or the distraction of the lessons taught on computers and phones because of the internet and computer problems. The discussion environment is quite insufficient in virtual education.

Lack of interaction in online learning during the pandemic was also seen in other contexts, for example, in Pakistan (Adnan and Anwar 2020), Jordan (Alawamleh et al., 2020), Poland (Bączek et al., 2021), and Malaysia (Tan, 2021).

Furthermore, it seems that the issue of 'lack of interaction' caused more problems, such as 'the tediousness of online lessons'. The Turkish higher education students stated that online learning was tedious 
and not encouraging enough. Some learners felt less motivated in online courses during this crisis because of 'lack of interaction', 'insufficient feedback', 'teacher's lectures and students' being passive recipients of information'. They clearly complained about inadequate active engagement in online class activities. The following are some of the excerpts from their responses.

The fact that eye contact with the teacher and the classroom environment during face-to-face training is more encouraging to learning cannot be denied. The most effective form of learning is face to face education.

I cannot get enough feedback; most of the time teachers give a lecture; I cannot interact with my classmates. Teachers are not well-prepared sometimes. All this makes classes boring.

Online learning is not very efficient compared to face to face education. Students are more active in the classroom environment and they communicate more effectively with each other and with their teachers during face-to-face learning, which makes it more efficient.

Moreover, Turkish university students in the current study explicitly stated that they were less concentrated in online courses. They referred to various reasons, such as 'personal issues', 'handling technical problems', 'lack of teacher's control or supervision', 'unsuitable home environment' as several distracting factors. The following are some of the excerpts from their responses.

Face-to-face education is more interesting and the students pay more attention. It is a problematic situation for a student, like me, who has concentration problems. Very often I cannot focus my attention on the online lessons.

We can't concentrate on lessons because we have to handle our computer or Wi-Fi connection problems.

It is difficult to focus on the lesson. The home environment, pyjamas, and constant snacking kill attention.

Face-to-face teaching helps students concentrate more while in online teaching some students can get distracted easily because there is nobody supervising them and catching their attention, sometimes they may lose their attention or get busy with other activities while the lesson is being taught.

Other studies also reported lack of concentration (Hussein et al., 2020; Subedi et al., 2020; Xhelili et al., 2021), lack of motivation (Alawamleh et al., 2020; Xhelili et, al. 2021), and inadequate engagement in online class activities (Sreehari, 2020; Xhelili, et al. 2021) as challenges of online instruction during the Corona Virus crisis.

The non-existence of a proper assessment procedure was the last drawback mentioned by the Turkish higher education students in the present study. Based on participants' responses, it seems that the tests used in EOT in Turkey do not comprehensively measure a student's competency and mastery of concepts in his/her field of study. Therefore, it seems that objective assessment of students' knowledge may not be possible. The following are the excerpts from their responses.

During the exams, students cheat by copying the answers from the book or searching the answers in Google, copying and pasting the answers to questions.

Since this crisis started, all our exams are online and include only multiple-choice questions. The teachers don't or maybe can't include all the important sections we studied. It seems they just select some parts by chance and make questions from them.

Before this situation, when classes were not online, the exams were harder. We had very few exams with multiple-choice questions. We had to write our answers or even our own analysis and interpretation of our studied points.

Frankly speaking, students get marks by cheating. Although many students like it, I think online exams can't show if a student has really learned the lesson or not!

Given the findings and mentioned points, universities in Turkey managed to switch from the traditional teaching to online learning, however, that hurried shift to online instruction was not fully satisfactory in Turkey.

The first and most frequently mentioned problem by the Turkish higher education students in the current study was 'inadequate technological infrastructure or facilities'. Every model of instruction entails its required infrastructure, without which favourable beneficial results cannot be achieved. Effective online education requires the provision of resources in order to assure quality: (1) selected technological delivery systems must be reliable; (2) learner support systems must be provided; (3) faculty professional development for online teaching must be supported. All the mentioned issues definitely entail government support. Consequently, all of these factors affect the effectiveness of online learning experiences (Moore, Lockee, and Burton, 2002). Even though these recommended areas are for well-planned online teaching and may not be perfectly possible in the case of the EOT, extra efforts are demanded in the case of the EOT during the Covid-19 pandemic in Turkey, especially in terms of provision of sufficient technology infrastructure to handle the requirements of EOT. As another option, asynchronous online lesson delivery is one way of alleviating some educational problems, such as the problem of inadequate technological infrastructure or 
facilities' (Villanueva et al., 2020). The flexibility of asynchronous online courses could be beneficial to all during this crisis (Dutton and Mohapatra, 2020).

The second-ranked issue causing dissatisfaction was "lack of sufficient teacher-student and peer interaction'. In fact, the presence of several types of classroom interaction enhances the learning outcomes in online distance education (Bernard et al., 2009). Therefore, careful planning for online learning must carefully consider different types of interactions which are essential to the learning process (Hodges et al., 2020).

The study showed that most of the Turkish higher education students were not satisfied with the preparedness of teaching staff for online teaching, which could be explained by the fact that the staff were forced to adapt to the changes due to the crisis. Since providing teachers with adequate training courses can help them effectively teach the courses via electronic delivery (Toquero, 2020), the teachers, especially future teachers, should be helped to enhance their skills needed for qualified online instruction (Amir et al., 2020; Korkmaz and Toraman, 2020; Toquero, 2020). In addition, the Turkish higher education students were not content with the quality or type of the training they received before starting the online learning. As Muthuprasad et al. (2021) truly said, "technical proficiency of teachers and learners related to usage of computer and internet is a major factor determining the effectiveness of online classes." (p. 7)

Considering some of the drawbacks stated by the higher education learners in Turkey, such as 'lack of learners' attention and concentration', 'Tediousness of online lessons', 'learners' inadequate engagement in class activities', and 'non-existence of comprehensive and accurate assessment procedure', and in view of the acute problems the country faces during the pandemic, it seems that flipped instruction can be one of the effective solutions for several fields of study because as O'Shea (2020) truly pointed out, the flexibility of flipped models of teaching has the potential to meet the learners' needs, especially in contexts where the learners complain about being disengaged and are merely passive recipients of information. Using flipped pedagogy, the content of instruction can be obtained via online videos prepared or provided by the teacher. Students watch the assigned instructional videos by themselves before class (Tang et al., 2020). Then the class time can incorporate various communicative activities, such as group work and interactive discussion (Basal, 2015; Danker, 2015; Egbert et al., 2015; Soltanpour and Valizadeh, 2018; Valizadeh and Soltanpour, 2020).

Collaborative approaches for learning via which the teacher is not the sole source of knowledge can be actualized utilizing the flipped approach to learning (O'Shea, 2020; Roehl, Reddy, and Shannon, 2013). In addition, instructors' provision of various learning materials to the learners before class lectures, leads to more time for learners' engagement during the lectures. Learners know about the lesson content at home; they, therefore, can be active during the class lectures by asking their questions, practising, and applying their already learned knowledge during class. Moreover, using this new approach, the professor can identify the low performing learners who need more help (Dressler and Rachfall, 2020; Klimplová, 2020).

\section{Conclusions}

The purpose of this article was to explore the Turkish higher education learners' attitudes towards EOT during the Covid-19 pandemic in order to discover the benefits and drawbacks of it. A mixed-methods design was used to achieve this aim. The analysis of both qualitative and quantitative data, which were gathered via 251 higher education learners' responses to close-ended and open-ended items of a questionnaire showed that the hurried shift to online instruction by universities in Turkey was not fully satisfactory although the participants stated that they felt safer during this pandemic disease by the availability of distant online education. Over half of the learners believed that students are compelled to learn through online learning and the majority of the respondents preferred face-to-face learning to an online format. The drawbacks they mentioned include 'inadequate technological infrastructure or facilities', 'lack of sufficient teacher-student and peer interaction', 'lack of learners' attention and concentration', 'tediousness of online lessons', 'learners' inadequate active engagement in class activities', as well as 'non-existence of comprehensive and suitable assessment procedure'.

The paper has put the argument for the flipped classroom to solve some drawbacks of the virtual education, such as 'lack of learners' attention and concentration', 'Tediousness of online lessons', 'learners' inadequate active engagement in class activities', and 'non-existence of comprehensive assessment procedure'; it is believed that flipped pedagogy could be useful for the higher education instruction in this crisis.

\section{References:}

Adnan, M., \& Anwar, K. (2020). Online learning amid the COVID-19 pandemic: Students' perspectives. Journal of Pedagogical Sociology and Psychology, 2(1), 45-51. https://doi.org/10.33902/JPSP. 2020261309.

Alawamleh, M., Al-Twait, L. M., \& Al-Saht, G. R. (2020). The effect of online learning on communication between instructors and students during Covid-19 pandemic. Asian Education and Development Studies. https://doi.org/10.1108/AEDS-06-2020-0131

Allo, M. D. G. (2020). Is the online learning good in the midst of Covid-19 Pandemic? The case of EFL learners. Jurnal Sinestesia, 10(1), 1-10. https://sinestesia.pustaka.my.id/journal/article/view/24. 
Amir, L. R., Tanti, I., Maharani, D. A., Wimardhani, Y. S., Julia, V., Sulijaya, B., \& Puspitawati, R. (2020). Student perspective of classroom and distance learning during COVID-19 pandemic in the undergraduate dental study program Universitas Indonesia. BMC Medical Education, 20(1), 1-8. https://doi.org/10.1186/s12909-020-02312-0

Bączek, M., Zagańczyk-Bączek, M., Szpringer, M., Jaroszyński, A., \& Wożakowska-Kapłon, B. (2021). Students’ perception of online learning during the COVID-19 pandemic: A survey study of Polish medical students. Medicine, 100(7), 1-6. https://doi.org/10.1097/MD.0000000000024821.

Barr, B. A., \& Miller, S. F. (2013). Higher education: The online teaching and learning experience. https://files.eric.ed.gov/fulltext/ED543912.pdf

Basal, A. (2015). The implementation of a flipped classroom in foreign language teaching. Turkish Online Journal of Distance Education, 16(4), 28-37. https://doi.org/10.17718/tojde.72185.

Baticulon, R. E., Sy, J. J., Alberto, N. R. I., Baron, M. B. C., Mabulay, R. E. C., Rizada, L. G. T., Tiu, C. J. S., Clarion, C. A., \& Reyes, J. C. B. (2021). Barriers to online learning in the time of COVID-19: A national survey of medical students in the Philippines. Medical Science Educator. https://doi.org/10.1007/s40670-021-01231-z.

Bernard, H. R. (2006). Research methods in anthropology: Qualitative and quantitative approaches (4th. ed.). Alta Mira Press.

Cakir, R., \& Solak, E. (2015). Exploring the factors influencing e-learning of Turkish EFL learners through TAM. Procedia - Social and Behavioral Sciences, 176, 596-601. https://doi.org/10.1016/j.sbspro.2015.01.515.

Cantrell, S. W., O’Leary, P., \& Ward, K. S. (2008). Strategies for success in online learning. Nursing Clinics of North America, 43(4), 547-555. https://doi.org/10.1016/j.cnur.2008.06.003

Chadha, G., \& Kumail, S. M. N. (2002). E-learning: An expression of the knowledge economy. McGraw-Hill.

Chen, H.-R., \& Tseng, H.-F. (2012). Factors that influence acceptance of web-based e-learning systems for the inservice education of junior high school teachers in Taiwan. Evaluation and Program Planning, 35(3), 398-406. https://doi.org/10.1016/j.evalprogplan.2011.11.007

Chung, E., Subramaniam, G., \& Dass, L. C. (2020). Online learning readiness among university students in Malaysia amidst COVID-19. Asian Journal of University Education (AJUE), 19, 46-58. https://doi.org/10.24191/ajue.v16i2.10294

Cinkara, E., \& Bagceci, B. (2013). Learners' attitudes towards online language learning; and corresponding success rates. Turkish Online Journal of Distance Education-TOJDE, 14(2), 118-130. https://files.eric.ed.gov/fulltext/EJ1013776.pdf

Creswell, J. W., \& Clark, V. L. P. (2011). Designing and conducting mixed method research (2nd ed.). Sage.

Danker, B. (2015). Using flipped classroom approach to explore deep learning in large classrooms. The IAFOR Journal of Education, 3(1), 171-186. http://files.eric.ed.gov/fulltext/EJ1100618.pdf.

Dressler, S., \& Rachfall, T. (2020). Improved learning performance based on a flipped classroom concept—A case study based on the course introduction to management accounting for business engineers. In Z. Walker, D. Tan, \& N. K. Koh (Eds.), Flipped classrooms with diverse learners: International perspectives (pp. 183-202). Springer Nature Singapore Pte Ltd.

Dube, B. (2020). Rural online learning in the context of COVID-19 in South Africa: Evoking an inclusive education approach. Multidisciplinary Journal of Educational Research, 10(2), 135-157. https://doi.org/10.4471/remie.2020.5607.

Dutton, Y. M., \& Mohapatra, S. (2020). COVID-19 and Law teaching: Guidance on developing an asynchronous online course for Law students. St. Louis University Law Journal, 2021, Forthcoming. https://doi.org/10.2139/ssrn.3604331.

Egbert, J., Herman, D., \& Lee, H. (2015). Flipped instruction in English language teacher education: A design-based study in a complex, open-ended learning environment. TESL-EJ, 19(2), 1-23. http://files.eric.ed.gov/fulltext/EJ1074707.pdf.

Erarslan, A., \& Topkaya, E. Z. (2017). EFL students' attitudes towards e-learning and effect of an online course on students' success in English. The Literacy Trek, 3(2), 80-101. https://dergipark.org.tr/en/pub/literacytrek/issue/32167/350186.

Eren, Ö. (2012). Students' attitudes towards using social networking in foreign language classes: A Facebook example. International Journal of Business and Social Science, 3(20), 288-294. http://www.ijbssnet.com/journals/Vol_3_No_20_Special_Issue_October_2012/32.pdf.

Erkut, E. (2020). Covid-19 Sonrasi Yüksekögretim [Higher education after Covid-19]. Yuksekogretim Dergisi - Journal of Higher Education (Turkey), 10(2), 125-133. https://doi.org/10.2399/yod.20.002

Guest, G., MacQueen, K. M., \& Namey, E. E. (2012). Applied Thematic Analysis. SAGE Publications, Inc.

Gunes, A. (2020, May). Pandemic could be an opportunity for Turkish higher education. University World News: The Global Window on Higher Education.

Hodges, C., Moore, S., Lockee, B., Trust, T., \& Bond, A. (2020). The difference between emergency remote teaching and online learning. EDUCAUSE Review. https://er.educause.edu/articles/2020/3/the-difference-between-emergency-remote-teachingand- online-learning

Hussein, E., Daoud, S., Alrabaiah, H., \& Badawi, R. (2020). Exploring undergraduate students' attitudes towards emergency online learning during COVID-19: A case from the UAE. Children and Youth Services Review, 119, 105699. https://doi.org/10.1016/j.childyouth.2020.105699

Ilgaz, H., \& Gülbahar, Y. (2015). A Snapshot of online Learners: E-readiness, e-satisfaction and expectations. International Review of Research in Open and Distributed Learning, 16(2), 171-187. https://doi.org/10.19173/irrodl.v16i2.2117

Inal, M., \& Korkmaz, Ö. (2019). The effect of web based blended learning on students' academic achievement and attitudes towards English course. Education and Information Technologies, 24(4), 2603-2619. https://doi.org/10.1007/s10639-019-09890-7.

Kamal, A., \& Radhakrishnan, S. (2019). Individual learning preferences based on personality traits in an E-learning scenario. Education and Information Technologies, 24(1), 407-435. https://doi.org/10.1007/s10639-018-9777-4.

Kaya, M. (2012). Distance education systems used in universities of Turkey and Northern Cyprus. Procedia - Social and Behavioral Sciences, 31(2011), 676-680. https://doi.org/10.1016/j.sbspro.2011.12.123

Khalil, R., Mansour, A. E., Fadda, W. A., Almisnid, K., Aldamegh, M., Al-Nafeesah, A., Alkhalifah, A., \& Al-Wutayd, O. (2020). The sudden transition to synchronized online learning during the COVID-19 pandemic in Saudi Arabia: A qualitative study exploring medical students' perspectives. BMC Medical Education, 20, 1-10. https://doi.org/10.1186/s12909-020-02208-z.

Klimplová, L. (2020). Flipping the business administration classroom. In Z. Walker, D. Tan, \& N. K. Koh (Eds.), Flipped classrooms with diverse learners: International perspectives (pp. 203-220). Springer Nature Singapore Pte Ltd.

Kohan, N., Arabshahi, K. S., Mojtahedzadeh, R., Abbaszadeh, A., Rakhshani, T., \& Emami, A. (2017). Barriers of self-directed learning in virtual environment Self-directed learning barriers in a virtual environment: a qualitative study. Journal of Advances in Medical Education \& Professionalism, 5(3), 116-123. https://jamp.sums.ac.ir/article_40998.html 
Korkmaz, G., \& Toraman, Ç. (2020). Are we ready for the Post-COVID-19 educational practice? An investigation into what educators think as to online learning. International Journal of Technology in Education and Science, 4(4), $293-309$. https://doi.org/10.46328/ijtes.v4i4.110

Moore, M., Lockee, B. \& Burton, J. (2002). Measuring Success: Evaluation Strategies for Distance Education. Educause Quarterly, 25(1), 20-26. Retrieved December 17, 2021 from https://www.learntechlib.org/p/92835/

Muthuprasad, T., Aiswarya, S., Aditya, K. S., \& Jha, G. K. (2021). Students' perception and preference for online education in India during COVID -19 pandemic. Social Sciences \& Humanities Open, 3(1), 100101. https://doi.org/10.1016/j.ssaho.2020.100101.

Nassaji, H. (2020). Good qualitative research. Language Teaching Research, $24(4), \quad 427-431$. https://doi.org/10.1177/1362168820941288

Njiku, J., Maniraho, J. F., \& Mutarutinya, V. (2019). Understanding teachers' attitude towards computer technology integration in education: A review of literature. Education and Information Technologies, 24(5), 3041-3052. https://doi.org/10.1007/s10639-019-09917-z

O’Shea, P. M. (2020). Flipped learning at the university level. In Z. Walker, D. Tan, \& N. K. Koh (Eds.), Flipped classrooms with diverse learners: International perspectives (pp. 171-182). Springer Nature Singapore Pte Ltd.

Pallant, J. (2013). SPSS survival manual: A step by step guide to data analysis using IBM SPSS (5th. ed.). Open University Press.

Patton, M. Q. (2014). Qualitative research and evaluation methods: Integrating theory and practice (4th. ed.). SAGE Publications, Inc.

Reichertz, J. (2014). Induction, deduction, abduction. In U. Flick (Ed.), The SAGE handbook of qualitative data analysis (pp. 123135). SAGE Publications Ltd.

Roehl, A., Reddy, S. L., \& Shannon, G. J. (2013). The flipped classroom: An opportunity to engage millennial students through active learning strategies. Journal of Family and Consumer Sciences, 105(2), 44-49. https://pdfs.semanticscholar.org/daa3/b94cdc7b52b3381a7c7e21022a7a8c005f84.pdf.

Salloum, S. A., Al-Emran, M., Shaalan, K., \& Tarhini, A. (2019). Factors affecting the E-learning acceptance: A case study from UAE. Education and Information Technologies, 24(1), 509-530. https://doi.org/10.1007/s10639-018-9786-3

Shahzad, S. K., Hussain, J., Sadaf, N., Sarwat, S., Ghani, U., \& Saleem, R. (2020). Impact of virtual teaching on ESL learners' attitudes under Covid-19 circumstances at post graduate level in Pakistan. English Language Teaching, 13(9), 1. https://doi.org/10.5539/elt.v13n9p1

Simsek, C. S. S. (2008). Students' attitudes towards integration of ICTs in a reading course: A case in Turkey. Computers and Education, 51(1), 200-211. https://doi.org/10.1016/j.compedu.2007.05.002

Soltanpour, F., \& Valizadeh, M. (2018). A flipped writing classroom: Effects on EFL learners' argumentative essays. Advances in Language and Literary Studies, 9(2), 5-13. https://doi.org/10.7575/aiac.alls.v.9n.2p.5.

Sreehari, P. (2020). Online learning during the Covid-19 lockdown: Learners' perceptions. Journal of Critical Reviews, 7(19), 300307. https://www.bibliomed.org/?mno=102109

Subedi, S., Nayaju, S., Subedi, S., Shah, S. K., \& Shah, J. M. (2020). Impact of e-learning during COVID-19 pandemic among nursing students and teachers of Nepal. International Journal of Science and Healthcare Research, 5(3), 68-76. https://ijshr.com/IJSHR_Vol.5_Issue.3_July2020/IJSHR0012.pdf

Syauqi, K., Munadi, S., \& Triyono, M. B. (2020). Students' perceptions toward vocational education on online learning during the COVID-19 pandemic. International Journal of Evaluation and Research in Education (IJERE), 9(4), 881-886. https://doi.org/10.11591/ijere.v9i4.20766.

Tallent-Runnels, M. K., Thomas, J. A., Lan, W. Y., Cooper, S., Ahern, T. C., Shaw, S. M., \& Liu, X. (2006). Teaching courses online: A review of the research. Review of Educational Research, 76(1), 93-135. https://doi.org/10.3102/00346543076001093

Tan, C. (2021). The impact of COVID-19 on student motivation, community of inquiry and learning performance. Asian Education and Development Studies, 10(2), 308-321. https://doi.org/10.1108/AEDS-05-2020-0084.

Tang, T., Abuhmaid, A. M., Olaimat, M., Oudat, D. M., Aldhaeebi, M., \& Bamanger, E. (2020). Efficiency of flipped classroom with online-based teaching under COVID-19. Interactive Learning Environments, 1-12. https://doi.org/10.1080/10494820.2020.1817761

Tekinarslan, E. (2008). Attitudes of Turkish distance learners toward internet-based learning: An investigation depending on demographical characteristics. The Turkish Online Journal of Distance Education, 9(1), 67-84. https://eric.ed.gov/?id=ED499478

Toquero, C. M. (2020). Challenges and opportunities for higher Education amid the COVID-19 pandemic: The Philippine context. Pedagogical Research, 5(4), em0063. https://doi.org/10.29333/pr/7947.

Unger, S., \& Meiran, W. (2020). Student attitudes towards online education during the COVID-19 viral outbreak of 2020: Distance learning in a time of social distance. International Journal of Technology in Education and Science, 4(4), 256-266. https://doi.org/10.46328/ijtes.v4i4.107

United Nations. (2020). Policy brief: Education during COVID-19 and beyond (Issue August). (2020). United Nations.

Uzun, A., \& Senturk, A. (2010). Blending makes the difference: Comparison of blended and traditional instruction on students' performance and attitudes in computer literacy. Contemporary Educational Technology, 1(3), $196-207$. https://www.cedtech.net/download/blending-makes-the-difference-comparison-of-blended-and-traditional-instruction-onstudents-6027.pdf

Valizadeh, M., \& Soltanpour, F. (2020). The Flipped Pedagogy: Effects on the Grammatical Competence and Writing Skill of Basic Users of English. International Journal of Instruction, 13(3), 761-776. https://doi.org/10.29333/iji.2020.13351a

Villanueva, M. E., Camilli, E., Chirillano, A. C., Cufré, J. A., De Landeta, M. C., Rigacci, L. N., Velazco, V. M., \& Pighin, A. F. (2020). Teaching instrumental analytical chemistry during covid-19 times in a developing country: Asynchronous versus synchronous communication. Journal of Chemical Education, 97(9), 2719-2722. https://doi.org/10.1021/acs.jchemed.0c00664

Xhelili, P., Ibrahimi, E., Rruci, E., \& Sheme, K. (2021). Adaptation and Perception of Online Learning during COVID-19 Pandemic by Albanian University Students. International Journal on Studies in Education, 3(2), 103-111. https://doi.org/10.46328/ijonse.49 